UDC $621.039,519.65$

\title{
INTERVAL MODELS OF TEMPERATURE CHARACTERISTICS OF SUPERHEATER SEPARATORS IN NUCLEAR POWER PLANT UNITS WITH THE CAPACITY OF 1000 MW
}

\author{
O.V. Yefimov, T.V. Potanina, V.L. Kavertsev, T.A. Harkusha, T.O. Yesypenko \\ National Technical University "Kharkiv Polytechnical Institute”, Kharkiv, Ukraine; \\ E-mail: AVEfimov@kpi.kharkov.ua
}

\begin{abstract}
The analysis of the influence of changes in the parameters of steam superheater separators SHS-1000 of nuclear power plant units with the capacity of $1000 \mathrm{MW}$ on the efficiency and safety of their operation, including the temperature characteristics at the nominal and partial operating modes of power units, has been carried out. Based on the experimental data of the thermal tests of the power unit, the temperature characteristic of the second stage of the SHS-1000 has been constructed in the form of the dependence of the temperature change of the heated steam at the second stage of the SHS on the change in the operating mode of the power unit. To create a correct mathematical model of this dependence, taking into account the limited amount of experimental data and the uncertainty of information about the structure and the probabilistic nature of measurement error during testing, the use of numerical methods of interval analysis has been proposed. Interval analysis has allowed to obtain an interval model that describes the receiver, which contains all possible values of the dependence of temperature change of the heated steam at the second stage of SHS on the unit operating mode (the electrical load). It has been shown that in conditions of limited initial data and uncertainty of information about it, numerical methods of interval analysis allow to create interval models of operational (energy) characteristics technological processes and equipment of NPP units with the maximum possible correspondence to real processes and objects, which is important to ensure high efficiency and safe operation of power units.
\end{abstract}

\section{INTRODUCTION}

Solving scientific and technical problems of increasing the efficiency, reliability and safety of the production of electric and thermal energy at nuclear power plants, as well as implementing the program to extend the long-term operation of nuclear power units, are urgent and strategic problems at the state level, directly related to the energy and economy of Ukraine, energy conservation and prevention of large-scale technological disasters, including those of cross-border nature [1].

In this regard, there is an increasing need in the development of new, more advanced methods for analyzing the quality and safety of the operation of nuclear power units, diagnosing the state and predicting the reliability indicators of their systems and equipment. This leads to the search for new and improvement of existing methods of mathematical modeling of technological processes and equipment characteristics of NPP units in order to determine reliability indicators and optimize parameters, to study the relationship between them when upgrading control systems of power units and their individual units and elements [2, 3]. The use of these methods in intelligent decision support systems at the stages of the life cycle of nuclear power units is of particular importance under the conditions of absence, significant limitation or uncertainty of information about changes in the parameters of technological processes in the units and equipment of power units $[4,5]$.

\section{INITIAL DATA AND STATEMENT OF THE PROBLEM}

One of the most urgent problems in the design and operation of turbines for saturated steam of the second circuit of WWER-1000 power units equipped with wet steam turbines of K-1000-60/1500-2 (K-1000-5.9/25) type is to reduce moisture content in the flow part of the low-pressure turbine cylinders (LPC). A high value of steam humidity (low dryness $x<0.88$ ) leads to a significant decrease in the internal efficiency of the lowpressure turbine (internal efficiency), erosion and corrosion of the turbine blade surface which can negatively affect the reliability and safety of the operation of both the turbine unit and the nuclear power unit as a whole.

To separate moisture from the steam flow after a two-line high-pressure cylinder (HPC) of the turbine and increase its temperature (overheating) before entering the two-line LPC in the turbines K-1000-60/ 1500-2 type of various modifications for nuclear power units with a WWER-1000 reactor superheater separator (SHS-1000) located in four buildings are used (Fig. 1). Each case of the superheater separators is a vertical cylindrical apparatus consisting of a louver type separator and two stages of the superheater in the form of surface-type heat exchangers located in the lower part of the case. After the HPC turbine with the degree of dryness $x=0.88$ (at the nominal operating mode) wet steam enters the inlet annular chamber, from which it is distributed through the inlet manifolds of the separator and sent to the louvered sheets, where moisture is separated and flows as a separator stream into the separator-collector (SC). The steam dried in the separator to the degree of dryness $x \geq 0.999$ (at the 
nominal operating mode) enters the annulus of the first stage of the superheater (SH-1), where it is additionally dried and partially overheated by the heating steam from the first selection of the HPC. The condensate of the heating steam SH-1 is sent to the condensate collector CC-1. The final superheating of the steam is carried out at the second stage of the superheater ( $\mathrm{SH}-2)$ by the heating steam from the collector for supplying "fresh" steam to the HPC. Its condensate is sent to the condensate collector $\mathrm{CC}-2$. Table 1 shows the averaged values of the parameters of heated and heating steam at the inlet and outlet of the SHS elements at the nominal operating mode of the power unit [6].

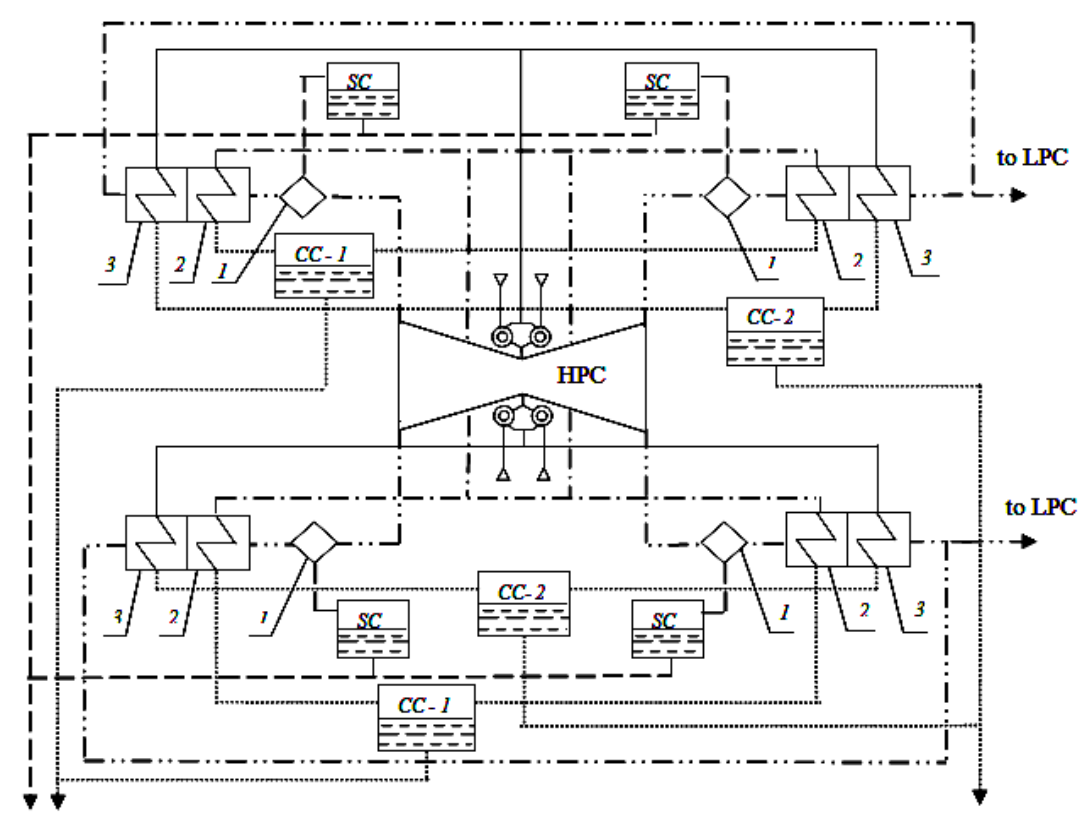

Fig. 1. Scheme of intermediate separation and superheating of steam in K-1000-60/1500-2 turbine of WWER-1000 NPP unit: 1 - SHS separation part; 2 - the first stage of overheating $\mathrm{SH}$-1; 3 - the second stage of overheating $\mathrm{SH}-2$

Table 1

Flow parameters of heated and heating steam at the inlet and outlet of elements of the SHS elements of the nuclear power unit with a capacity of $1000 \mathrm{MW}$ at nominal operating mode

\begin{tabular}{|c|c|}
\hline Index & Value \\
\hline $\begin{array}{l}\text { Parameters of wet steam flows at the inlet to the separators: } \\
\text { pressure, } \mathrm{MPa} \\
\text { degree of dryness }\end{array}$ & $\begin{array}{l}1.20 \\
0.88\end{array}$ \\
\hline $\begin{array}{l}\text { Parameters of wet steam flows at the outlet of the separators: } \\
\text { pressure, } \mathrm{MPa} \\
\text { degree of dryness }\end{array}$ & $\begin{aligned} & 1.18 \\
\geq & 0.999\end{aligned}$ \\
\hline $\begin{array}{l}\text { The total consumption of separated moisture entering the } \\
\text { deaerators, } t / h\end{array}$ & 590.0 \\
\hline $\begin{array}{l}\text { Parameters of heating steam flows coming from the first } \\
\text { turbineselection to the first stages of superheaters: } \\
\text { pressure, } \mathrm{MPa} \\
\text { degree of dryness } \\
\text { total consumption (in } 4 \text { SHS cases), } \mathrm{t} / \mathrm{h}\end{array}$ & $\begin{array}{l}2.98 \\
0.93 \\
170.0\end{array}$ \\
\hline $\begin{array}{l}\text { Parameters of heating steam flows coming from "fresh" steam } \\
\text { pipelines to the second stages of superheaters: } \\
\text { pressure, MPa } \\
\text { degree of dryness } \\
\text { total consumption (in } 4 \text { SHS cases), t/h }\end{array}$ & $\begin{array}{l}5.89 \\
0.995 \\
270.0\end{array}$ \\
\hline $\begin{array}{l}\text { Parameters of heated steam flows at the outlet of the SHS: } \\
\text { pressure, } \mathrm{MPa} \\
\text { temperature, }{ }^{\circ} \mathrm{C}\end{array}$ & $\begin{array}{c}1.14 \\
250.0\end{array}$ \\
\hline
\end{tabular}

The main characteristics by which the efficiency of the power plant, and, therefore, the efficiency, reliability and safety of the power unit can be evaluated, are the temperature characteristics of the plant as an important part of the set of operational (energy) characteristics of power units with WWER $[6,7]$. In general terms, they are a multi-parameter function of the heated steam temperature at the outlet of the overheating stages of the SHS $t_{\text {hed }_{i}}^{\text {out }}, i=1,2$ from the operating and design parameters:

$$
t_{\text {hed }_{i}}^{\text {out }}=f\left(t_{\text {hed }_{i}}^{\text {in }}, t_{\text {hing }_{i}}^{\text {in }}, D, x_{i}, F_{i}\right),
$$


where $t_{\text {hed }_{i}}^{\text {in }}$ - temperature of the heated steam at the inlet to the overheating stage; $t_{\text {hing }}^{\text {in }}$ - temperature of heating steam at the inlet to the overheating stage; $D$ consumption of heated steam; $x_{i}$ - degree of dryness of the heated steam at the inlet to the overheating stage; $F_{i}$ - effective heat exchange surface of the overheating stages.

Since the parameters $t_{\text {hed }_{i}}^{\text {in }}, t_{\text {hing }_{i}}^{\text {in }}, D, x_{i}$ are functions of the operating mode of the power unit (electric load $N) t_{\text {hed }_{i}}^{\text {in }}=f_{1}(N), t_{\text {hing }_{i}}^{\text {in }}=f_{2}(N), D=$ $f_{3}(N), x_{i}=f_{4}(N)$, then

$$
t_{\text {hed }_{i}}^{\text {out }}=f_{5}\left(N, F_{i}\right), i=1,2 .
$$

In the normative technical condition of the heat exchange surfaces of the overheating stages, the temperature characteristics of the SHS can be considered as functions that depend on the load of the power unit only:

$$
t_{\text {hed }_{i}}^{\text {out }}=f(N), i=1,2 .
$$

The temperature characteristics of SHS-1000 at nominal and partial operating modes of a $1000 \mathrm{MW}$ nuclear power unit have a significant impact on the change in its main indicators: electric power $N$ and specific heat consumption $q$. For example, at the nominal operating mode of a $1000 \mathrm{MW}$ power unit, the decrease in the temperature of the heated steam after $\mathrm{SH}-1$ by $1^{\circ} \mathrm{C}$ leads to the decrease in the power of the power unit by $288 \mathrm{~kW}(0.027 \%)$ and to the increase in the specific heat consumption by $2.57 \mathrm{~kJ} /(\mathrm{kW} \cdot \mathrm{h})$ $(0.024 \%)$, and the decrease in its temperature by $1{ }^{\circ} \mathrm{C}$ after SH-2 leads to the decrease in power by $213 \mathrm{~kW}$ $(0.020 \%)$ and to the increase in the specific heat consumption by $1.5 \mathrm{~kJ} /(\mathrm{kW} \cdot \mathrm{h})(0.014 \%)$ [7].

The analysis of the influence of the temperature characteristics of the SHS at partial operating modes of the power unit on its main performance indicators $N$ and $q$ showed that the influence of $\mathrm{SH}-1$ parameters decreases with the decrease in "fresh" steam consumption, and the influence of $\mathrm{SH}-2$ parameters increases. This is explained by the fact that, as the power unit decreases at constant parameters of "fresh" steam, the thermal load of $\mathrm{SH}-2$, and therefore its influence on $N$ and $q$, increases, while the heat load of $\mathrm{SH}-1$, which is fed with the steam from the first turbine selection, decreases. The reason for this is the increase in the difference between the enthalpy of heating and heated steam at the inlet to SH-2 and the decrease in this difference in SH-1.

The abovementioned determines the relevance of constructing adequate mathematical models of the dependences of the temperature change of the heated steam in the SHS-1000 stages on the operating mode (electrical load) of a $1000 \mathrm{MW}$ nuclear power unit in order to determine correctly temperature values.

In $[6,7]$, experimental data are presented on measuring the temperature of heated steam at the outlet of the first and second stages of the SHS when the electric load $N$ of WWER-1000 NPP power unit changes in the range of $50 \ldots 100 \% N_{\text {nom }}$ (Table 2). The values of steam temperatures were obtained during thermal tests of the power unit at Zaporizhzhya NPP [8], which were carried out with the turbine shut-off and control valves fixed for the corresponding operating mode, that is, with a constant volumetric flow rate of "fresh" steam at the test mode.

Obviously, these experimental data contain inaccuracies and have interval uncertainty, that is, the unknown true value of the measured parameter is in a certain interval. The uncertainty is caused by measurement and rounding errors, noise, incomplete information. The analysis of numerous scientific papers [9-25] devoted to the processing of experimental data characterized by uncertainty, shows that the interval model can be considered one of the most adequate models.

For a wide range of problems dealing with building a model based on the results of the experiment, the formalized dependence is the following:

$$
y=\varphi(\mathbf{x}, \mathbf{b})+\varepsilon_{y},
$$

where $\mathbf{x}=\left(x_{1}, \ldots, x_{n}\right) \in X-$ vector of input variables, $\mathbf{b}$ - vector of model parameters; $y$-output variable; $\varphi$ is a function that describes the deterministic component of the dependence of $y$ on $\mathbf{x}$, and $\varepsilon_{y}$ - quantity that describes the uncertainty of the presented dependence.

In the probabilistic model which is the most common among other methods of constructing a model of the relationship between the input and output variables, the component $\varepsilon_{y}$ is a normally distributed random variable with the mathematical expectation zero and the standard deviation $\sigma_{y}$. The uncertainty of the variable $\mathrm{y}$ for a given confidence probability is described by the confidence interval (the so-called $" 2-\sigma$ " rule):

$$
\hat{y}-2 \sigma_{y} \leq y \leq \hat{y}+2 \sigma_{y},
$$

where $\hat{y}$ - point estimation of the unknown values $\mathrm{y}$ obtained as a result of the experiment.

The interval model [9] does not impose requirements on the submission of the absolute error $\varepsilon_{y}$ to any distribution law, but considers only its limitation: $\left|\varepsilon_{y}\right| \leq \varepsilon$. This suggests that the value $\hat{y}$ was obtained with the well-known error $\varepsilon_{y}$. Then for any value of $\hat{y}$ there is an uncertainty interval:

$$
\boldsymbol{y}=\left[\hat{y}-\varepsilon_{y}, \hat{y}+\varepsilon_{y}\right]
$$

moreover, the interval can always be extended when new sources of errors and the possibility of quantifying them are detected.

Table 2

Thermal test data of K-1000-60/1500-2 turbine unit of WWER-1000 nuclear power unit

\begin{tabular}{|l|c|c|c|c|c|c|}
\hline \multicolumn{1}{|c|}{$N, \%$} & 50 & 60 & 70 & 80 & 90 & 100 \\
\hline $\begin{array}{l}\text { Steam temperature at the outlet of } \\
\text { the first stage of the SHS, } T 1,{ }^{\circ} \mathrm{C}\end{array}$ & 180.5 & 187.0 & 192.0 & 195.0 & 196.0 & 198.0 \\
\hline $\begin{array}{l}\text { Steam temperature at the outlet of } \\
\text { the second stage of the SHS, } T 2,{ }^{\circ} \mathrm{C}\end{array}$ & 258.0 & 257.0 & 256.0 & 254.0 & 252.5 & 251.0 \\
\hline
\end{tabular}


The uncertainty of temperature measurements arising at the use of thermocouples and resistance thermometers to measure the temperature of the coolant (steam) at nuclear power plants is influenced by many factors. These are the most important of them: random effects in the measurement; uncertainty of the recording instrument measurement; the tolerance class of thermocouple and resistance thermometer; changes in the characteristics of thermocouple and resistance thermometer between calibrations; additionally for thermocouple accuracy class of the extension wire connecting the thermocouple with the recording device and the uncertainty of the temperature compensation of the reference junction.

According to the "Guide of uncertainty in measurement" [23] the uncertainty generated by the above sources are considered random variables, which are normally evenly symmetrical or asymmetrical distribution. The sample presented in Table 2, contains a rather limited number of experimental points - only six measurements, and the structure and probabilistic characteristics of measurement errors are unknown. Thus, it is impossible to justify the use of standard experimental data processing procedures that rely on statistical methods and require representativeness of the sample (its length should be sufficiently large), normal distribution of measurement errors, and exact values of the main argument.

In such a situation, more objective information about the real values of the dependence of the temperature of the steam heated in the SHS on the electric load of the power unit, which, as it was shown above, are very important from the point of view of ensuring the efficiency, reliability and safety of the power unit operation, can be obtained by means of numerical methods of interval analysis [24, 25].

Let us consider the application of these methods to construct an interval model of the dependence of the temperature change of the heated steam at the outlet of SH-2 on the load of the power unit.

\section{RESULTS AND THEIR DISCUSSION}

In the interval model, the inaccuracy or uncertainty of the output parameter (in our case, steam temperature T2) is described by the interval $\mathbf{t}=[\underline{\mathbf{t}}, \overline{\mathbf{t}}]$, where $\underline{\mathbf{t}}$ and $\overline{\mathbf{t}}$ are the lower and upper boundaries of this interval, respectively. The interval determines the set of possible values of the unknown true parameter T2. The peculiarity of the interval approach is that no probability or fuzzy value is specified in this interval $t$, that is, all values in the interval are equally possible.

As the proposed structure of the dependence which is being determined between the variable $N$ - the load of the power unit $(\%)$ and the output variable $T 2$ - the temperature of the steam at the outlet of the second stage of the SHS, we take the following linear dependence:

$$
T 2(N, b 1, b 2)=b 1+b 2 \cdot N+\varepsilon,
$$

where $b 1, b 2$ - parameters.

The following quantities from expression (6) are the subject of evaluation: the set of real values of the parameters is "information set" [22] and the range of real values of the dependence (6).

The experimental data (see Table 2 ) are presented by the sample:

$$
\left\{T 2_{i}, N_{i}, i=1, \ldots, n\right\},
$$

where $T 2_{i}$ is the measured value of the temperature of the steam at the load of the power unit $N_{i} ; \mathrm{n}=6$ is the sample length (Fig. 2).

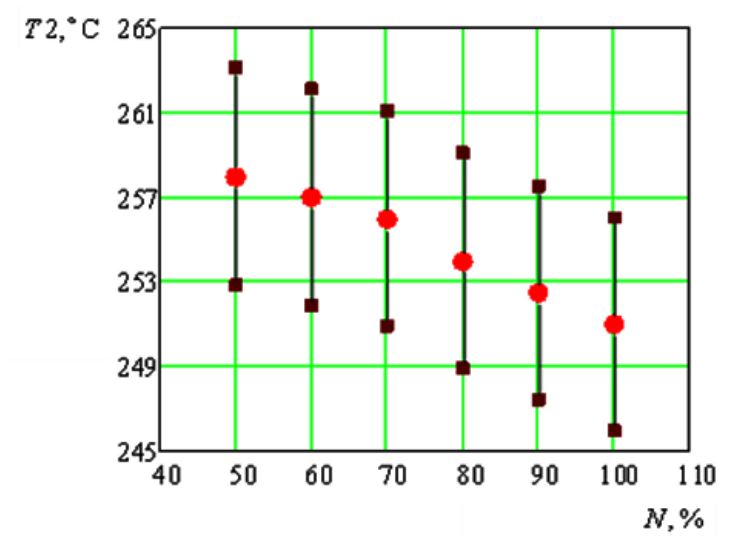

Fig. 2. Experimental data:

$\bullet--$ steam temperature at the outlet of the second stage of the SHS at a fixed load of the power unit N, \% [6]; vertical bars - uncertainty intervals

As it has already been noted, in the conditions of thermal tests of the turbine unit, the values of electric power $N_{i}$ are determined with some error. In order to measure the power as accurately as possible, the following measures are usually taken at the terminals of the generator:

- the choice of measuring transformers with an actual error in the operating measurement range of up to $\pm(0.1 \ldots 0.2) \%$ and taking measures that reduce errors to a minimum (due to the difficulty of their accounting). In particular, in order to avoid overload, it is necessary to check the actual load of the measuring transformers, minimizing it;

- elimination of harmful effects on the accuracy of measurement;

- connection of measuring instruments as close as possible to the output terminals and to any branch through which leakage or supply of energy from outside can occur;

- the use of two independent measurement methods simultaneously.

Measurements of temperature values $T 2$ contain noise errors. Resistance thermocouples, with the help of which the temperature of the coolant (steam) at nuclear facilities is measured, have a device error of $\pm(0.15+$ $0.002|t|){ }^{\circ} \mathrm{C}$ or $\pm(0.3+0.005|t|){ }^{\circ} \mathrm{C}$, depending on the tolerance class [26]. In addition, it is necessary to take into account the error, the value of which is indicated in the metrological standards.

The given measurement error takes into account all the components of the measurement error of the parameter: methodological, instrumental, subjective. When measuring the temperature of the steam in the pipeline behind the SHS, this reduced error when measured directly by the primary device, is $1.5 \%$, the 
readings and recording by secondary devices are determined with the error of $2 \%$.

Thus, for each experimental value:

$$
T 2_{i}=\widehat{T 2}_{i}+\varepsilon_{\mathrm{i}},\left|\varepsilon_{\mathrm{i}}\right| \leq \varepsilon_{\max }, i=1, \ldots, 6,
$$

where $T 2_{i}$ - steam temperature measurement result; $\widehat{T 2}_{i}-$ unknown true value of its temperature; $\varepsilon_{\mathrm{i}}-$ the error of the $i-$ th measurement; the maximum value of the error $\varepsilon_{\max }$ is about $5{ }^{\circ} \mathrm{C}$.

For each steam temperature measurement, the lower $\mathbf{T} 2_{i}$ and the upper $\overline{\mathbf{T} 2}$ boundaries of the uncertainty interval $\mathbf{T} 2_{i}$ are calculated:

$$
\begin{aligned}
\mathbf{T} 2_{i} & =\left[\mathbf{T} 2_{i}, \overline{\mathbf{T} 2}{ }_{i}\right], i=1, \ldots, 6 ; \\
\overline{\mathbf{T} 2_{\boldsymbol{i}}} & =T 2_{i}+\varepsilon_{\max } ; \\
\mathbf{T} 2_{\boldsymbol{i}} & =T 2_{i}+\varepsilon_{\max } .
\end{aligned}
$$

The physical meaning of the uncertainty interval is the range of possible values of the steam temperature, containing an unknown true value which is being measured.

The set of uncertainty intervals (see Fig. 2) can be written as follows:

$$
\begin{aligned}
& \left\{\boldsymbol{T} 2_{i}\right\}=\{[252.84,263.16],[251.86,262.14], \\
& {[250.88,261.12],[248.92,259.08],} \\
& [247.45,257.55],[245.98,256.02]\} .
\end{aligned}
$$

Each uncertainty interval $\mathbf{T} 2_{i} i=1, \ldots, 6$ contains possible values of the measurand which are consistent with this measurement, that is, at least one dependence curve (7) can be drawn through all the uncertainty intervals. For each pair of uncertainty intervals $\mathbf{T} 2{ }_{i}$ and $\mathbf{T} 2_{j}, i=1, \ldots, 5, j=i+1, \ldots, 6$, (10) of the measurement sample, a two-parameter "partial information set" $G_{i, j}(b 1, b 2)$ of parameters $b 1, b 2$ [24], which are compatible with this pair of uncertainty intervals, is calculated.

The next step is to determine the information set $I(b 1, b 2)$ of the parameters $b 1, b 2$, compatible with the entire sample of measurements:

$$
I(b 1, b 2)=\bigcap_{i=1, \ldots, 5, j=i+1, \ldots, 6} G_{i, j}(b 1, b 2) .
$$

For (7) and (10) we have the following restrictions for constructing the information set:

$$
\begin{gathered}
T 2_{i}-\varepsilon_{\max } \leq b 1+b 2 \cdot N_{i} \leq T 2_{\mathrm{i}}+\varepsilon_{\max } \\
i=1, \ldots, 6 .
\end{gathered}
$$

Therefore, these conditions take the following form:

$$
\begin{aligned}
& 252.84 \leq b_{1}+50 \cdot b_{2} \leq 263.16, \\
& 251.86 \leq b_{1}+60 \cdot b_{2} \leq 262.14, \\
& 250.88 \leq b_{1}+70 \cdot b_{2} \leq 261.12, \\
& 248.92 \leq b_{1}+80 \cdot b_{2} \leq 259.08, \\
& 247.45 \leq b_{1}+90 \cdot b_{2} \leq 257.55, \\
& 245.98 \leq b_{1}+100 \cdot b_{2} \leq 256.02 .
\end{aligned}
$$

Formal application of the rule for constructing information set leads to the following result: the set $I(b 1, b 2)$ is a polygon with seven vertices, and parameter $b 2$ is a quantity with different signs:

$\{(b 1, b 2)\}=$ $=\{(252.84,0),(249.66,0.0636),(256.02,0)$,

(257.74, -0.098), (262.31, -0.16333),

$(280.34,-0.3436),(270.3,-0.1428)\}$.

However, the analysis of the experimental data (see Table 2) and the above-described features of the technological process of drying and superheating of steam in SHS (see Fig. 1) shows that dependence (7) is a function that decreases with the increase in electric load. Therefore, it makes sense to require that the parameter $b 2<0$. Therefore, with the new restriction for the parameters, the information set $I(b 1, b 2)$ takes the form of a polygon with six vertices (Fig. 3 - the region with black fill):

$$
\begin{aligned}
& I(b 1, b 2): \mathbf{b}^{1}=(b 1, b 2)=(252.84,0), \\
& \mathbf{b}^{2}=(256.02,0), \\
& \mathbf{b}^{3}=(270.3,-0.1428), \\
& \mathbf{b}^{4}=(280.34,-0.3436), \\
& \mathbf{b}^{5}=(262.31,-0.16333), \\
& \mathbf{b}^{6}=(257.74,-0.098) .
\end{aligned}
$$

This set is characterized by unconditional minimal external estimates - parameter intervals $[\underline{\mathbf{b 1}}, \overline{\mathbf{b 1}}]$ and $[\underline{\mathbf{b 2}} ; \overline{\mathbf{b 2}}]$. The estimation of these intervals is carried out according to the rules:

$\mathbf{b 1}=[\underline{\mathbf{b 1}} ; \overline{\mathbf{b 1}}]: \underline{\mathbf{b 1}}=\operatorname{Arg}\{\min \quad b 1 \in I(b 1, b 2)\}$,

$\overline{\mathbf{b 1}}=\operatorname{Arg}\{\max \quad b 1 \in I(b 1, b 2)\}$;

$\mathbf{b 2}=[\underline{\boldsymbol{b 2}} ; \overline{\boldsymbol{b} 2}]: \underline{\mathbf{b 2}}=\operatorname{Arg}\{\min \quad b 2 \in I(b 1, b 2)\}$

$\overline{\mathbf{b} 2}=\operatorname{Arg}\{\max \quad b 2 \in I(b 1, b 2)\}$.

Extreme corner points determine the size of the set $I(b 1, b 2)$ (the rectangle marked by the dashed line in Fig. 3) and the boundaries of the intervals b1 and $\mathbf{b} 2: \mathbf{b}^{1}=(252.84,0), \mathbf{b}^{4}=(280.34,-0.3436)$. Then

$$
\mathbf{b} 1=[252.84,280.34], \mathbf{b} 2=[-0.3436,0] .
$$

The interval approach allows to build a refined tube $T 2(N)$ of the so-called guaranteed valid dependencies (characteristic values). Such a tube is determined by its lower $\underline{\mathbf{T} 2}\left(N_{i}\right)$ and upper $\overline{\mathbf{T} 2}\left(N_{i}\right)$ boundaries, calculated using the information set in the following way:

$$
\mathbf{T} 2(N)=\left\{\underline{\mathbf{T} 2}\left(N_{i}\right), \overline{\mathbf{T} 2}\left(N_{i}\right)\right\}, i=1, \ldots, 6,
$$

where $\underline{\mathbf{T} 2}\left(N_{i}\right)=\min _{(b 1, b 2) \in I(b 1, b 2)}\left\{b 1+b 2 \cdot N_{i}\right\}$,

$\overline{\mathbf{T} 2}\left(N_{i}\right)=\max _{(b 1, b 2) \in I(b 1, b 2)}\left\{b 1+b 2 \cdot N_{i}\right\}$.

That is (Fig. 4):

$\left\{\underline{\mathbf{T} 2}\left(N_{i}\right)\right\}=$

$=\{252.84,251.86,250.877,249.244,247.61,245.977\}$,

$\left\{\overline{\mathbf{T} 2}\left(N_{i}\right)\right\}=$

$=\{263.16,261.732,260.304,258.876,257.448,256.02\}$.

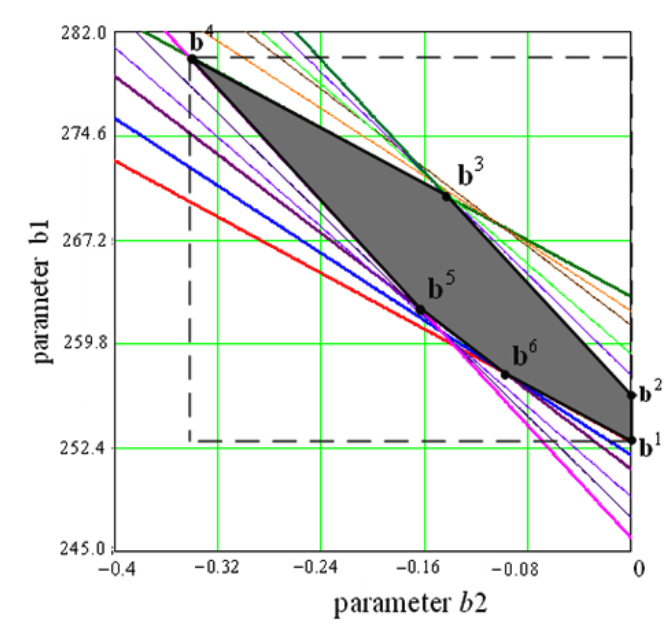

Fig. 3. The information set $I(b 1, b 2)$ 
It should be noted that, as it can be seen from Fig. 4, in some points the actual tube width is narrower than the uncertainty intervals.

As a result, the interval model of the dependence of the temperature of the heated steam at the outlet of the second stage of the SHS on the electrical load of the power unit can be presented as follows:

$[T 2(N)]=$

$$
=[252.84,280.34]+[-0.3436,0] \cdot N \text {. }
$$

Using point estimates of the parameters $\hat{b} 1, \hat{b} 2$ of the unknown coefficients of the output variable model (steam temperature at the outlet of the second stage of the SHS) with the fixed vector of the input variable (electric load of the power unit), we can construct a point estimate that defines some forecast model.

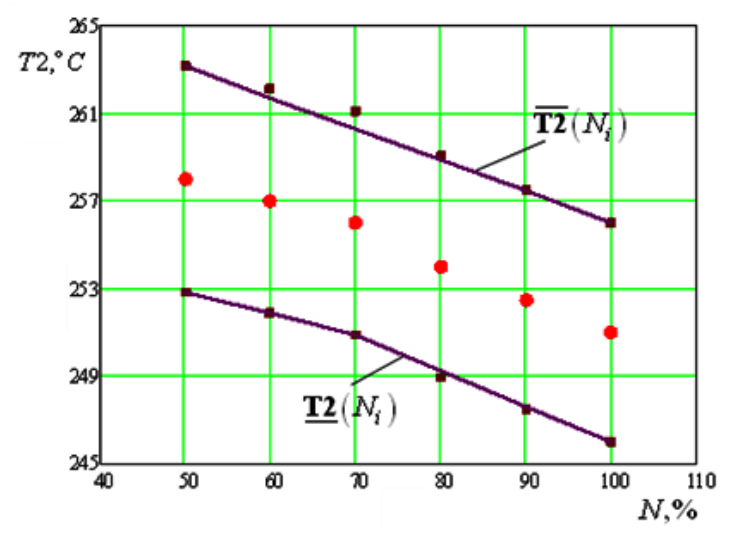

Fig. 4. The boundaries of the tube of guaranteed acceptable characteristic values

Parameter estimation using the "uncertainty center method" [27] is the following:

$$
\begin{gathered}
\hat{b} 1_{c}=0.5(\underline{\mathbf{b} 1}+\overline{\mathbf{b} 1}), \hat{b} 2_{c}=0.5(\underline{\mathbf{b} 2}+\overline{\mathbf{b} 2}), \\
\hat{b} 1_{c}=266.59, \hat{b} 2_{c}=0.1718 .
\end{gathered}
$$

Therefore, the forecast line has the following form:

$$
\widehat{T 2}(N)=266.59-0.1718 \cdot N \text {. }
$$

Using standard statistical approaches for processing experimental data, let us determine the parameters of the relationship (7) using the least squares method [28]. Then, the resulting equation will be the following:

$$
\widehat{T 2}(N)=265.571-0.144 \cdot N
$$

the standard deviation is $\sigma=0.33$. The graph of the linear approximation by the least square method $T 2_{\text {mnk }}(N)$ is shown in Fig. 5 (line 1).

Another estimation was performed using the "maximum matching method" $[18,25]$, which is used to determine the dependences from data with interval uncertainty and determines the points at which the best agreement between the data and the dependence parameters is obtained as a solution. In this case, the predicted dependence $T 2$ maxmatch $(N)$ has the form:

$$
\widehat{T 2}(N)=265.588-0.1428 \cdot N \text {. }
$$

As it can be seen from Fig. 5, point estimates (23) and (24) are fairly close.

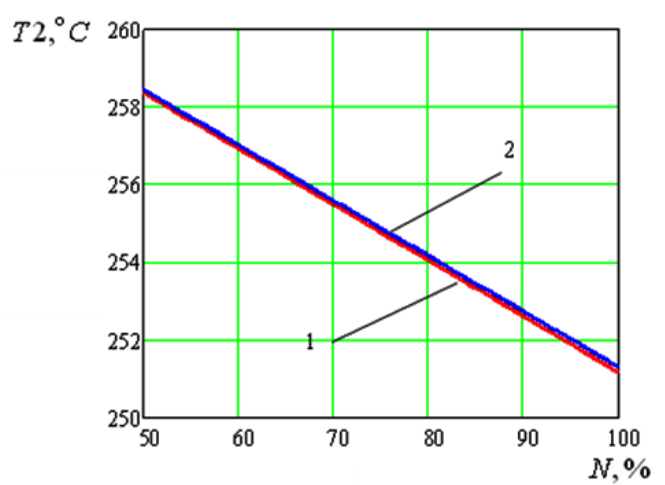

Fig. 5. Models for predicting the dependence of the temperature of the heated steam $T 2$ at the outlet of the second stage of the SHS on the electric load N:

1 -MNK-estimate $T 2_{m n k}(N) ; 2$ - the estimate constructed using the "maximum matching method" $T 22_{\text {maxmatch }}(N)$

\section{CONCLUSIONS}

While solving the problems of the estimation of safety and reliability of systems and equipment of NPP units, as well as improving the efficiency of their operation based on the analysis of operational (energy) characteristics including temperature characteristics of SHS, there remains the problem of accounting uncertainty in the simulated objects and processes and the choice of mathematical apparatus for their description. The classic "point" representation of variables in problems of modeling and optimization does not often allow to achieve the maximum possible conformity between the real object and its model. Ignoring the interval nature of the problem leads to the solution in the form of some "exact" numbers. The proximity of such solutions to the lower potential and, respectively, the upper values of the interval cannot be estimated. In the practice of the NPP unit exploitation in the conditions of optimization of technological processes it can lead, in some cases, to erroneous solutions from the point of view of the estimation of indicators of safety and reliability.

In such a situation, the advantage of data processing as well as determining and constructing NPP unit performance models by the interval analysis method tools which allow to take into account inaccuracies in the setting of initial data, measurement error, parameters uncertainty, multi-mode operational nature of such complex systems as nuclear power units, are obvious.

Therefore, the application of the mathematical technique of interval analysis, its features and benefits is promising for solving a wide range of problems of the increase in efficiency of nuclear power units, evaluation of their safety and reliability on the basis of valid interval operational characteristics in the conditions of uncertain initial data.

\section{REFERENCES}

1. Report on the state of nuclear and radiation safety in Ukraine in 2018. Kyiv, 2019, 70 p. Access mode: http://www.snrc.gov.ua/nuclear/doccatalog/document?i $\mathrm{d}=425406$. Date of application: January 1, 2020. 
2. A.V. Yefimov, M.V. Maximov, Yu.V. Romashov. Loss of stability and the form of a possible bend of the guide channels of the fuel assemblies of nuclear reactors WWER-1000 // Nuclear and Radiation Safety. 2015, N 4(68), p. 14-18.

3. A.V. Yefimov, Yu.V. Romashov. Problem of evaluation for structural materials operability in elements of nuclear power plants equipments // Problems of Atomic Science and Technology. 2017, N 2, p. 29-35.

4. A.V. Yefimov, D.I. Kukhtin, T.V. Potanina, T.A. Harkusha, V.L. Kavertsev. Automated decision support for operating personnel of NPP power units by the criterion of technical and economic efficiency, taking into account reliability indicators // Nuclear and Radiation Safety. 2018, N 2(78), p. 11-19.

3. O.V. Yefimov, M.M. Pylypenko, T.V. Potanina, T.A. Yesypenko, V.L. Kavertsev, T.A. Harkusha. Components of the automated intellectual systems supporting decisions at the stage of operation and equipment diagnostics nuclear power units // Problems of Atomic Science and Technology. 2020, N 1(125), p. 127-134.

6. V.A. Buzlukov, M.G. Teplitsky, L.B. Oyberman, A.V. Yefimov, A.A. Palagin, E.D. Menshikova. Obtaining the characteristics of the equipment of turbine units by the method of field experiment // Thermal Engineering. 1987, N 8, p. 19-21.

7. A.A. Palagin, A.V. Yefimov, V.A. Kostrykin, E.D. Menshikova, V.A. Buzlukov, M.G. Teplitsky, L.B. Oyberman. The study of the modes and structure of turbine units using simulation models // Thermal Engineering. 1987, N 10, p. 41-46.

8. Thermal tests of K-1000-60/1500-2 POAT KhTZ turbine unit and a power unit of $1000 \mathrm{MW}$ st. №1 of Zaporizhzhya NPP: Report on scientific research of Yuzhtekhenergo, №G. 12748. Lviv, 1987, 140 p.

9. R.E. Moore, R.B. Kearfott, M.J. Cloud. Introduction to interval analysis. Philadelphia: "Society for Industrial and Applied Mathematics", 2009, 223 p.

10. T.V. Potanina, A.V. Yefimov, T.A. Harkusha, T.A. Yesypenko. The use of interval analysis methods to assess the safety and reliability of nuclear power units // Nuclear and Radiation Safety. 2018, N 3, p. 23-29.

11. L. Jaulin, M. Kieffer, O. Didrit, E. Walter. Applied Interval Analysis. London: "Springer-Verlag Ltd Publ.", 2001, 379 p.

12. M.P. Divak. Problems of mathematical modeling of static systems with interval data. Ternopil: "Economic Thought of TNEU", 2011, 216 p.

13. M.W. Gutowski. Interval experimental data fitting. Focus on Numerical Analysis. NY: "Nova Science Publishers", 2006, p. 27-70.

14. A.P. Voshchinin. Interval data analysis: development and prospects // Factory Laboratory. Diagnostics of materials. 2002, v. 68, N 1, p. 118-126.
15. A.V. Kryukov, A.I. Litvintsev. Interval modeling of modes of electric power systems in phase coordinates // Modern technologies. System analysis. Modeling. 2014, N 4(44), p. 57-62.

16. O.E. Rodionova. Interval method for processing the results of multichannel experiments: Dis. ... Dr. Phys. Sciences. M., 2008, 273 p.

17. A. Grishkevich. Interwałowe oszacowania wskaźników niezawodności strukturalnej systemów elektroenergetycznych na podstawie metod optymalizacji // Prace naukowe Akademii im. Jana Długosza w Częstochowie. ,Technika, Informatyka, Inżyneria Bezpieczeństwa”. 2014, v. II, p. 91-106.

18. S.P. Shary. Maximum consistency method for data fitting under interval uncertainty // Journal of Global Optimization. 2016, v. 66, issue 1, p. 111-126.

19. V. Kreinovich. Interval methods for data fitting under interval uncertainty: a probabilistic treatment // Reliable Computing. 2016, v. 23, p. 105-140.

20. A.V. Yefimov, M.M. Pylypenko, T.V. Potanina, T.A. Yesypenko, T.A. Harkusha, Yu.S. Stadnik. Processing of experimental data of the process of refining nuclear material $\mathrm{Zr} 1 \% \mathrm{Nb}$ by electron-beam melting by means of interval analysis methods // Problems of Atomic Science and Technology. 2019, N 5(123), p. 118-123.

21. T.V. Potanina, O.V. Yefimov. Application of interval analysis methods to determine the operational characteristics of NPP power units // Bulletin of the National Technical University "KhPI". Series "Hydraulic machines and hydraulic units". 2019, N 2, p. 77-81.

22. A.V. Yefimov, T.V. Potanina. Application of interval analysis for improving reliability of estimation of hardness value spread for nuclear structural materials // Problems of Atomic Science and Technology. 2020, N 1(125), p. 206-210.

23. Guide to the Expression of Uncertainty in Measurement: First ed. ISO, Switzerland, 1993, 101 p.

24. S.I. Kumkov. Processing of experimental data on the ionic conductivity of molten electrolyte by interval analysis methods // Melts. 2010, N 3, p. 79-89.

25. S.P. Shary. The problem of dependency recovery from data with interval uncertainty // Factory Laboratory. Diagnostics of materials. 2020, v. 86, N 1 , p. 62-74.

26. DSTU 2858:2015. Thermocouples of resistance. General technical requirements and test methods: Nat. standard of Ukraine. Kyiv: "Ministry of Economic Development of Ukraine", 2017, 22 p.

27. S.I. Zhilin. Experiments on the estimation of empirical dependence parameters by the least squares method and the uncertainty center method // Bulletin of the Altai State University. 2003, № 1, p. 24-27.

28. Yu.V. Linnik. Least squares method and the basics of observation processing theory. L.: "Fizmatgiz", 1962, 352 p. 


\title{
ИНТЕРВАЛЬНЫЕ МОДЕЛИ ТЕМПЕРАТУРНЫХ ХАРАКТЕРИСТИК СЕПАРАТОРОВ- ПАРОПЕРЕГРЕВАТЕЛЕЙ ЭНЕРГОБЛОКОВ АЭС МОЩНОСТЬЮ 1000 МВТ
}

\author{
А.В. Ефимов, Т.В. Потанина, В.Л. Каверцев, Т.А. Гаркуша, Т.А. Есипенко
}

Проведен анализ влияния изменения параметров сепараторов-пароперегревателей СПП-1000 энергоблоков АЭС мощностью 1000 МВт на эффективность и безопасность их работы, в том числе значений температурных характеристик на номинальном и частичном режимах работы энергоблоков. На основании экспериментальных данных тепловых испытаний энергоблока построена температурная характеристика второй ступени СПП-1000 в виде зависимости изменения температуры нагреваемого пара на второй ступени СПП от изменения режима работы энергоблока. Для создания корректной математической модели этой зависимости с учетом ограниченного количества экспериментальных данных и неопределенности информации о структуре и вероятностном характере погрешностей измерений при испытаниях предложено использование численных методов интервального анализа. Интервальный анализ позволил получить интервальную модель, описывающую «трубку», которая содержит все возможные значения зависимости изменения температуры нагреваемого пара на второй ступени СПП от режима работы энергоблока (электрической нагрузки). Показано, что в условиях ограниченности исходных данных и неопределенности информации о них численные методы интервального анализа позволяют создавать интервальные модели эксплуатационных (энергетических) характеристик технологических процессов и оборудования энергоблоков АЭС с максимально возможным соответствием реальным процессам и объектов, что важно для обеспечения высокой эффективности и безопасной эксплуатации энергоблоков.

\section{ІНТЕРВАЛЬНІ МОДЕЛІ ТЕМПЕРАТУРНИХ ХАРАКТЕРИСТИК СЕПАРАТОРІВ ПАРОПЕРЕГРІВНИКІВ ЕНЕРГОБЛОКІВ АЕС ПОТУЖНІСТЮ 1000 МВТ}

\section{О.В. Сфімов, Т.В. Потаніна, В.Л. Каверцев, Т.А. Гаркуиа, Т.О. Ссипенко}

Проведено аналіз впливу зміни параметрів сепараторів пароперегрівників СПП-1000 енергоблоків АЕС потужністю 1000 МВт на ефективність і безпеку їх роботи, в тому числі значень температурних характеристик на номінальному і часткових режимах роботи енергоблоків. За експериментальними даними результатів теплових випробувань енергоблоку побудована температурна характеристика другого ступеня СПП-1000 у вигляді залежності зміни температури пари, що гріється у другому ступені СПП, від зміни режиму роботи енергоблоку. Для створення коректної математичної моделі цієї залежності, враховуючи обмежену кількість експериментальних даних і невизначеність інформації про структуру і вірогідний характер помилок і похибок вимірювань під час випробувань, запропоновано застосування чисельних методів інтервального аналізу. Ці методи дозволили отримати інтервальну модель, що описує «трубку», в якій містяться всі можливі значення залежності зміни температури пари, що гріється у другому ступені СПП, від режиму роботи енергоблоку (електричної потужності). Показано, що в умовах обмеженості вихідних даних і невизначеності інформації про них чисельні методи інтервального аналізу дозволяють створювати інтервальні моделі експлуатаційних (енергетичних) характеристик та технологічних процесів, що відбуваються в устаткуванні енергоблоків АЕC, з максимально можливою їх відповідністю реальним процесам та об’єктам, що важливо для забезпечення високої ефективності і безпеки роботи енергоблоків. 